\title{
REINTERPRETATION OF THE CAMBRIAN 'BRYOZOAN' PYWACKIA AS AN OCTOCORAL
}

\author{
PAUL D. TAYLOR, ${ }^{1}$ BJÖRN BERNING, ${ }^{2}$ AND MARK A. WILSON ${ }^{3}$ \\ ${ }^{1}$ Department of Earth Sciences, Natural History Museum, Cromwell Road, London SW7 5BD, UK, $<$ p.taylor@nhm.ac.uk>; ${ }^{2}$ Oberösterreichische \\ Landesmuseen, Geowissenschaftliche Sammlungen, Welserstrasse 204060 Linz-Leonding, Austria, <b.berning@landesmuseum.at>; and \\ ${ }^{3}$ Department of Geology, The College of Wooster, Wooster, OH 44691, USA, <mwilson@wooster.edu>
}

\begin{abstract}
Pywackia baileyi Landing in Landing et al., 2010, from the upper Cambrian Yudachica Member of Oaxaca State, southern Mexico, consists of small, phosphatic, proximally tapering cylindrical rods covered by shallow polygonal calices. The bryozoan-like morphology of this fossil prompted its interpretation as the first bryozoan known from the Cambrian. However, restudy of some of the original material, employing scanning electron microscopy for the first time, questions the assignment of Pywackia to the Bryozoa. Striking similarities between Pywackia and the modern pennatulacean octocoral Lituaria lead to an alternative hypothesis interpreting Pywackia an early fossil octocoral. While Pywackia is probably not a true pennatulacean, a group with a definitive fossil record stretching back only to the Late Cretaceous, it can be envisaged as having had a similar skeletal structure and ecology to Lituaria, the rods representing mineralized axes of tiny colonies that lived with their proximal ends buried in the sediment and distal ends covered by feeding polyps. Landing et al. (2010) considered the phosphatic composition of Pywackia specimens to be the result of diagenetic replacement, but the evidence is equivocal. If Pywackia had a primary phosphatic skeleton, this would support the hypothesized existence of phosphatic biomineralization early in the evolutionary history of Cnidaria, as well as providing further evidence that Pywackia is not a bryozoan.
\end{abstract}

\section{INTRODUCTION}

$\mathrm{M}$ UCH HAS been written about the Cambrian explosion. Importantly, all animal phyla with biomineralized skeletons make their first appearance in the Cambrian, with the notable exception of the Bryozoa. Most species of modern bryozoans have calcareous skeletons, and this is well reflected by the rich fossil record of these colonial lophotrochozoans. Nevertheless, there are no unequivocal Cambrian bryozoans and the undisputed fossil history of the phylum does not begin until the Early Ordovician (Taylor and Ernst, 2004). Several claims of the existence of bryozoans of Cambrian age have been made in the past but none have stood up to close scrutiny. Notable among these are some unnamed putative bryozoans described by Cobbold (1931) and by Cobbold and Pocock (1934), from Comley and Rushton, respectively, in Shropshire, England, and two species of Archaeotrypa Fritz, 1947, from the upper Cambrian of Alberta, Canada. The material from Shropshire has been examined by one of us (PDT) and appears to consist of pieces of pitted arthropod exoskeleton. The zig-zag 'zooecial' walls of Archeotrypa prima Fritz, 1947 in longitudinal section raise serious doubt about its identity as a bryozoan but, unfortunately, Kobluk's (1984) revision of this species, as well as the poorly preserved $A$. secunda Fritz, 1947, proved inconclusive.

The latest fossil claimed to be a Cambrian bryozoan is Pywackia baileyi Landing, 2010, described from the late Cambrian of southern Mexico in Landing et al. (2010). The aim of the current paper is to re-evaluate the taxonomic affinity of Pywackia, based on a study of topotypic material. This is the first investigation to use scanning electron microscopy (SEM) on this fossil. The evidence for Pywackia being a bryozoan is questioned and an alternative interpretation is proposed that it is an octocoral with an originally phosphatic skeleton and a colonial morphology resembling that seen in the recent pennatulacean Lituaria.

\section{MATERIAL AND METHODS}

Through the courtesy of Ed Landing (New York State Museum) we were able to examine a cavity slide (NYSM Tu2.05) containing more than 50 specimens of Pywackia baileyi Landing in Landing et al., 2010. Although these specimens were not designated as primary types and are not figured in the original paper, they are part of the "nearly 150 stem-like fragments" obtained from the three localities by Landing et al. (2010, p. 548) and are clearly conspecific with the holotype (NYSM 13515; Landing et al. 2010, fig. 2K). Individual specimens from this slide are referred to below by the cell number.

Studied specimens come from the Yudachica Member of the Tinu Formation, near Rio Salinas village, Oaxaca State, southern Mexico. Landing et al. (2007) dated the Yudachica Member as uppermost upper Cambrian (upper 'Olenidian Series'). Samples yielding Pywackia were obtained from the basal part of the Yudachica Member, which falls within the Corylodus andresi conodont zone of Baltica, correlating with the Laurentian Eoconodontus notchpeakensis conodont subzone (Landing et al., 2007, fig. 4). The Yudachica Member is a thin (up to $16 \mathrm{~m}$ ), condensed deposit comprising interbedded limestones and silty shales, interpreted as a temperate zone carbonate deposited in the photic zone. Episodic high-energy, wave-dominated deposition was apparently punctuated by intervals during which the bottom sediments, and possibly the bottom waters too, were poorly oxygenated. During these times, phosphatization of gastropods, hyoliths, brachiopods, ostracods and trilobites apparently occurred beneath the oxygen minimum layer, with some of the phosphatized fossils later being exhumed and eroded on the sea floor (Landing et al., 2007, p. 913). All of the material of Pywackia was recovered as insoluble, phosphatic residues after breakdown of Yudachica Member limestones using formic acid. 


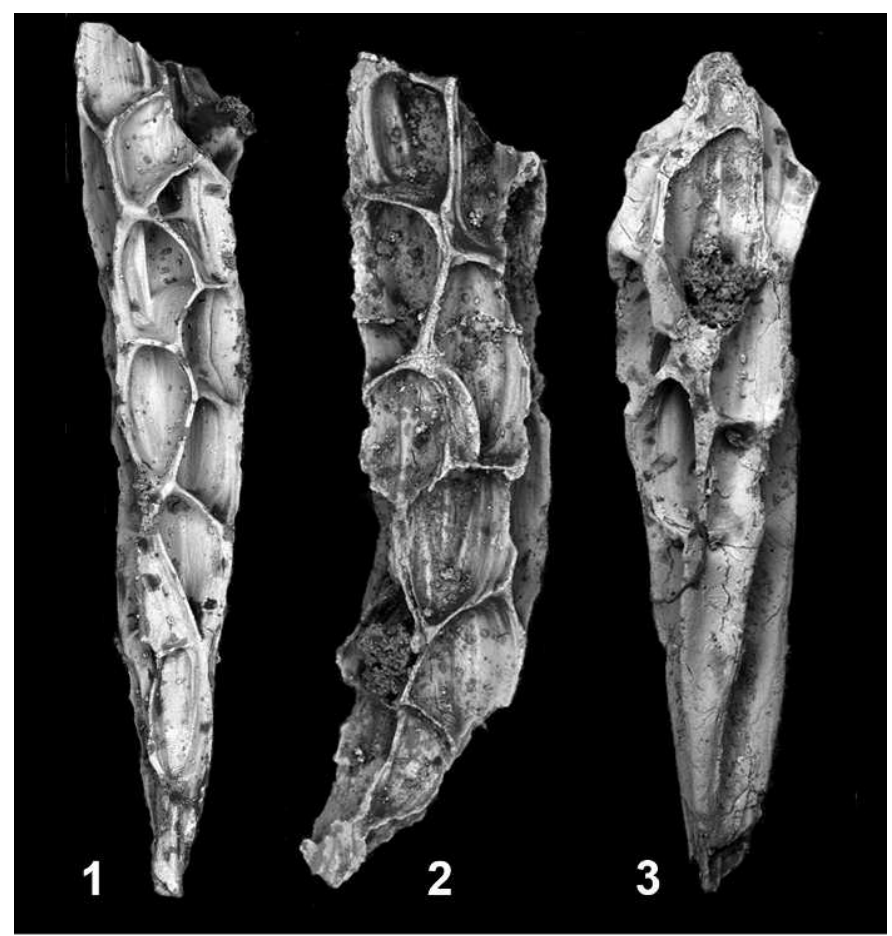

FiguRE 1 -Back-scattered scanning electron micrographs of the putative bryozoan Pywackia baileyi from the upper Cambrian Yudachica Member of Oaxaca State, Mexico, NYSM Tu-2.05. 1, well preserved rod tapering towards the proximal end, cell $36, \times 31 ; 2$, unusual curved rod, cell $29, \times 47 ; 3$, rod with longitudinal walls slightly torted, cell $7, \times 34$.

Comparative material was studied from the fossil bryozoan collections of the Natural History Museum, London (NHM), and the recent pennatulacean octocoral collections of the NHM and the Muséum national d'Histoire naturelle, Paris (MNHN). Additional material of an unnamed species of the pennatulacean Lituaria ('sea-pencil') was kindly collected on our behalf by S. K. Tan (Raffles Museum, Singapore; abbreviated RMS) from a sand flat in the intertidal zone near the Changi Ferry Terminal, Singapore.

The cavity slide containing specimens of Pywackia was initially studied using an optical microscope prior to detailed SEM examination. The availability of a low vacuum SEM (LEO 1455-VP) enabled the entire cavity slide to be placed in the large specimen chamber without the need for coating or detachment of the Pywackia specimens affixed to it. Imaging was undertaken using backscattered electrons. As no attempt was made to clean these delicate specimens, traces of sediment, pyrite and possibly glue, which have a different molecular weight than the skeleton of Pywackia, are visible in the micrographs as darker or lighter areas. Recent material of Lituaria was bleached to remove all organic material and expose the underlying skeleton before scanning.

\section{MORPHOLOGY OF PYWACKIA}

Specimens of Pywackia comprise spindle-shaped, invariably straight rods that do not bifurcate (Fig. 1.1). One rod is an exception in showing slight bending at the proximal end (Fig. 1.2). All examples are fragmented to varying degrees, being broken at the tapering proximal end, the broader distal end, or both ends. The original description of $P$. baileyi lacked any explicit data on size, apart from that which could be calculated from the magnifications of the figures. The longest (incomplete) rod in the cavity slide studied measured $3 \mathrm{~mm}$. In a subsample of 25 SEM-imaged specimens, rod width averaged $0.59 \mathrm{~mm}$ (SD $0.137 \mathrm{~mm}, \mathrm{CV} 24.4$ ), with a range of $0.32-0.80 \mathrm{~mm}$.

Presumed proximal ends of rods could be observed to taper at varying rates. In some instances tapering is rapid and the proximal end is moderately rounded, but in others tapering is slower and the proximal end appears more pointed (Fig. 1.1, 1.3). Landing et al. (2010, fig. 2J) illustrated what they interpreted to be an "apical tip", the rod in question seemingly having a rounded distal end. However, in most specimens the distal end is incomplete, often with clear evidence having been fractured.

Rod surfaces are covered by an array of polygonal, calyx-like modular units (Figs. 1.1, 1.2, 2.3) defined by walls perpendicular to the rod axis. These units were interpreted by Landing et al. (2010) as autozooecia but are here referred to as modules to avoid the connotation that Pywackia is necessarily a bryozoan. The modules generally form 4 to 6 series around the circumference of the rod and tend to be arranged in alternating series. However, there are irregularities in the patterning of the modules reflecting their variability in shape and size. While most of the modules are 6-sided and have six neighbors, some are 3-, 4-, 5-, or 7-sided, with a corresponding number of neighboring modules. Modules are invariably longer than wide, ranging from $0.27-0.59 \mathrm{~mm}$ in length and $0.15-0.38 \mathrm{~mm}$ in width. Exceptionally, however, modules at the tapering proximal end of the rods may be at least $1.25 \mathrm{~mm}$ long and very narrow. Slight torsion of the longitudinal walls bounding these apical modules is occasionally evident (Fig. 1.3). Individual modules extend almost to the centers of the rods and can be at least $0.33 \mathrm{~mm}$ in depth (Fig. 2.1).

Landing et al. (2010) identified three types of individuals in Pywackia: normal 'autozooecia', small, nanozooecia-like polymorphs located at some autozooecial corners, and tube-like axial zooids. The small polymorphs could represent modules at the extreme end of the spectrum of small size rather than being discrete polymorphs. The presence of axial zooids is neither clearly demonstrated in the figures of Landing et al. (2010), nor have our SEM investigations revealed their existence: end views of a rod (Fig. 2.1) suggest that modules extend all the way to the center of the rod without space for an axial zooid.

The basic polygonal, cup-shaped morphology of the modular units in Pywackia is complicated by the presence of a variety of structures developed in some but not all modules. Landing et al. (2010, fig. 2K, L) figured "bilobed keels" forming low longitudinal ridges (i.e., oriented parallel to the rod axis) on the module basal walls. Such keels seem more often to comprise single structures without bilobation (Fig. 2.2). Longitudinally elliptical holes are visible adjacent to the keels in at least one rod, but it is unclear whether these are original or taphonomic in origin. Basal walls of modules are marked by numerous longitudinal lineations of low relief in a few rods (Fig. 2.6). Partial subdivision of some modules is brought about by the development of transverse to obliquely transverse walls of generally higher relief than the longitudinal keels (Fig. 2.4, 2.5). These walls resemble those bounding each module but are shallower and differ from most bounding walls (cf. Fig. 2.7) in not extending to the very outside of the rod. An unusual dipping, diaphragm-like wall has been observed in one module (Fig. 2.8).

Wall surfaces are smooth and relatively flat apart from a mild crenulation. There are no spines, tubercles or pores. The ends of walls are well rounded (Fig. 2.9). Broken walls show thickness to range from about 10 to $20 \mu \mathrm{m}$ and may reveal a tripartite substructure with dense outer layers, up to $5 \mu \mathrm{m}$ in thickness, sandwiching a less dense central layer containing voids (Fig. 2.10, 2.11). 

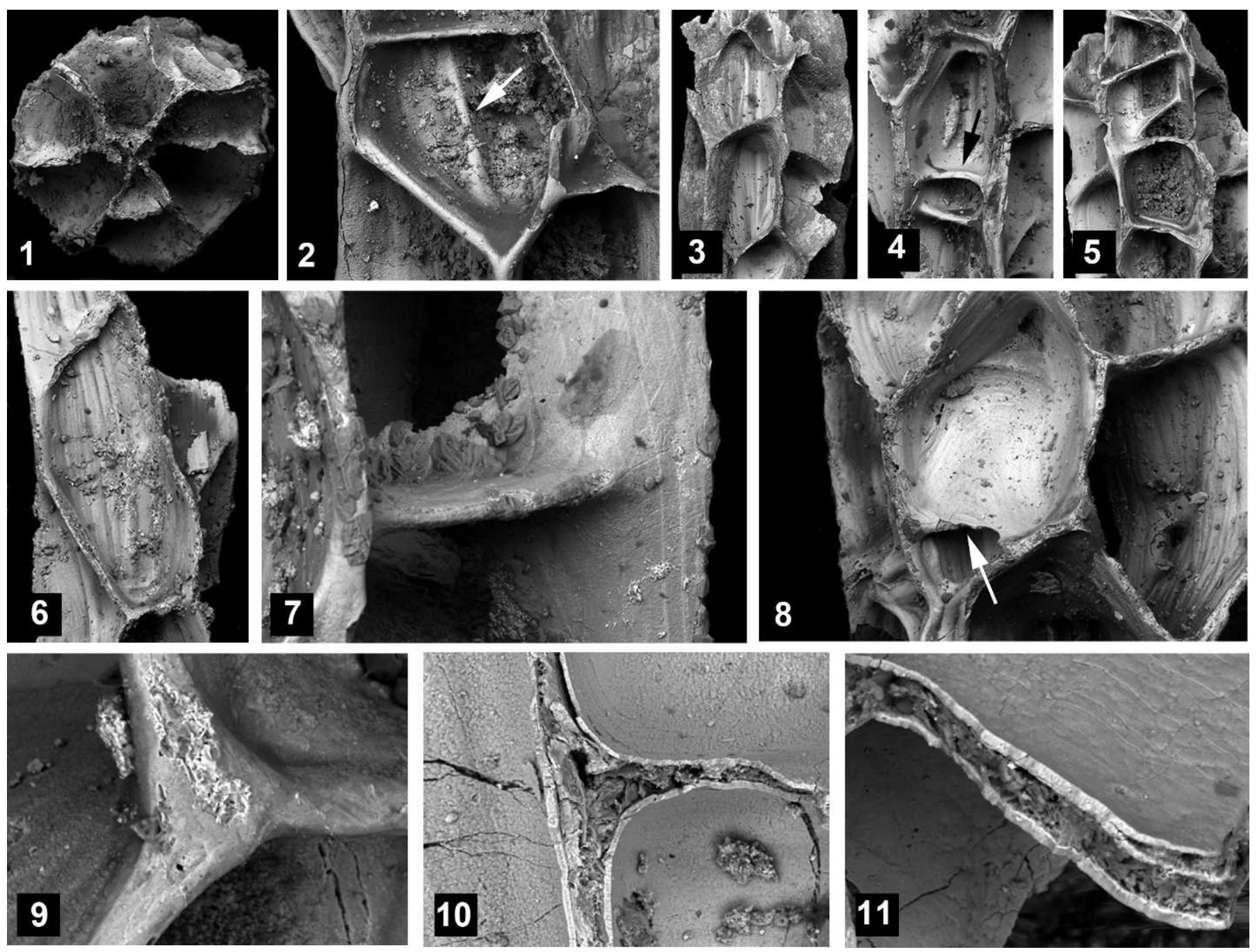

FIGURE 2-Back-scattered scanning electron micrographs of the putative bryozoan Pywackia baileyi from the upper Cambrian Yudachica Member of Oaxaca State, Mexico, showing details of the modules and skeletal walls, NYSM Tu-2.05. 1, distal end of a rod showing apparent lack of an axial, stolon, cell 13, $\times 54 ; 2$, five-sided module with a slightly oblique longitudinal keel at the base (arrow), cell $2, \times 100 ; 3$, well preserved rod with longitudinal fabric at the base of the modules, cell $1, \times 36 ; 4$, module partly subdivided by a transverse wall (arrow), cell 20, $\times 60 ; 5$, modules containing oblique transverse walls, cell 20, $\times 40$; 6 , broken module with longitudinal striations on the basal wall, cell $3, \times 82 ; 7$, transverse wall bounding a module but not extending fully to the outside of the rod, cell 44, $\times 210 ; 8$, unusual dipping, diaphragm-like wall slightly broken at the edge (arrow), cell $24, \times 125$; 9, detail of smooth wall surface at triple junction between three modules, cell $36, \times 650 ; 10,11$, broken walls showing dense outer layers and median layer containing voids, cell $34 ; 10, \times 370 ; 11, \times 600$.

BRYOZOAN VERSUS OCTOCORAL AFFINITIES

Inferring the phylum-level affinity of Pywackia demands comparison with appropriate organisms, preferably living, of certain identity to ascertain which provides the closest match. Ideally, one should seek synapomorphies (shared homologous features). This is notoriously difficult in organisms of simple skeletal morphology, particularly when this morphology is also plastic, as in Pywackia. Here we summarize the hypothesis of Landing et al. (2010) that Pywackia is a bryozoan, and present an alternative hypothesis interpreting it as an octocoral.

Bryozoan hypothesis.-Landing et al. (2010) believed Pywackia to be a Cambrian bryozoan. In particular, they compared it with cryptostomes, a group of stenolaemate bryozoans well known from post-Cambrian Paleozoic rocks. Implicitly, their comparison was with rhabdomesine (Fig. 3) rather than ptilodictyine cryptostomes as the former have narrow, equidimensional branches like Pywackia, whereas the latter have flattened, bifoliate branches, often robust, that do not resemble Pywackia. They pointed to the presence of axial zooids in Pywackia as evidence for a cryptostome affinity; axial zooids are present in cryptostomes such as Rhabdomeson (see Wyse Jackson and Bancroft, 1995) but seem not to be developed in any other Paleozoic bryozoan groups. Other lines of evidence used by Landing et al. (2010) to support a bryozoan affinity were the presence of keels, indicating a bilaterally (e.g., metazoan) rather than radially (e.g., hydrozoan) symmetrical animal, and polymorphism, which they used to rule out a coral affinity. They further pointed out that the tapered proximal end, bilamellar wall construction, shallow autozooecia, diaphragms (Landing et al., 2010, fig. 2H) and hemiphragms (Landing et al., 2010, fig. 2G) of Pywackia are all features that can be found among cryptostome bryozoans. Although the size of the modules was not specified in the original paper, the submillimetric diameters $(0.15-0.59 \mathrm{~mm})$ are also consistent with a bryozoan affinity.

Nevertheless, important aspects of the morphology of Pywackia are inconsistent with the bryozoan model. The modules of Pywackia are shallow cups on the rod surface, whereas the zooids of cryptostomes and other mineralized Paleozoic bryozoans are tubular (e.g., Blake, 1983, fig. 268; Dzik, 1994, fig. 9e), narrow initially and expanding in diameter towards the aperture. This 


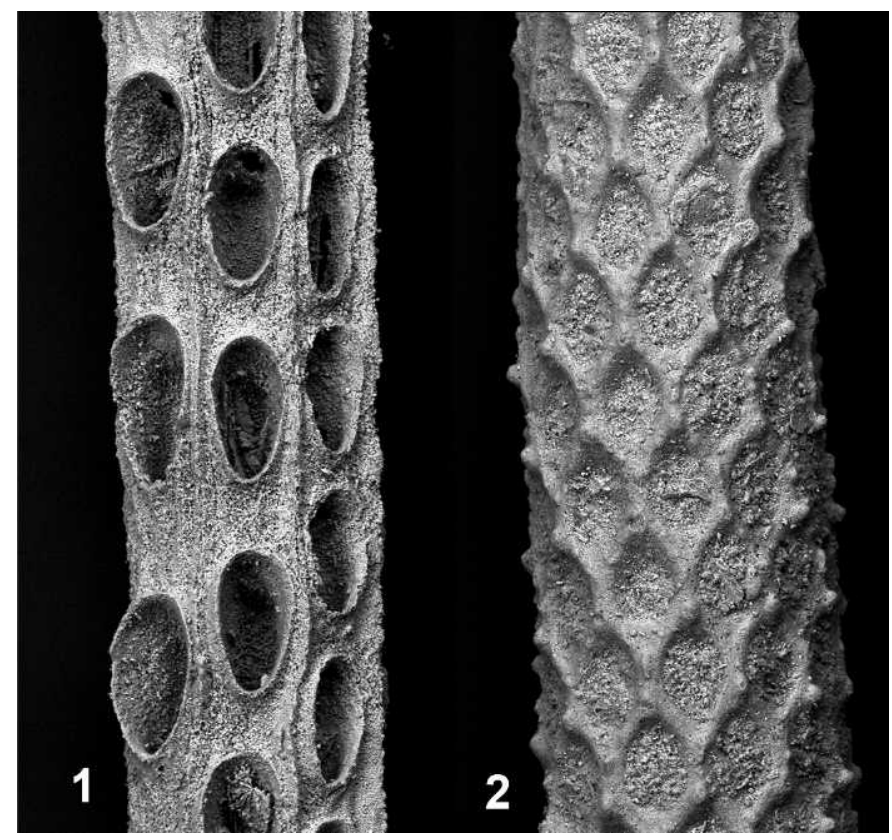

FIGURE 3-Back-scattered scanning electron micrographs of representative rhabdomesine cryptostome bryozoans for comparison with Pywackia. 1, arthrostylid Nematopora lineata (Billings, 1862), calcium fluoride-replaced branch showing aligned autozooids with elliptical apertures, NHM BZ 5983 Ordovician, Ashgill, Ojl Myr flint, Gotland, Sweden, $\times 42 ; 2$, rhabdomesid Rhabdomeson progracile Wyse Jackson and Bancroft, 1995, sediment-filled, hexagonal apertures of autozooids arranged quincuncially and separated by skeletal walls covered by short styles, NHM BZ 5982, Lower Carboniferous, Haimyres, East Kilbride, Scotland, $\times 42$.

morphology gives them a clear polarity, lacking in the modules of Pywackia. The irregularity and morphology of the various structures within the modules would also be unusual for a bryozoan. While complete transverse partitions (diaphragms), partial transverse partitions (hemiphragms) and less frequently blade-like structures (Hinds, 1973) do occur in a range of bryozoans, these have regular morphologies and distributions within species. The low profile keels and longitudinal lineations visible on the bases of some Pywackia modules have no obvious analogues among bryozoans.

Interpretation of the tapering proximal ends of the rods raises a further problem. Landing et al. (2010, p. 548) implied that a tapered end for substrate attachment was a feature of bryozoans, but this is not the case. Instead, cryptostome and other Paleozoic bryozoans most often have expanded colony bases cemented to hard or firm substrates. Exceptions can be found among some ptilodictyine and arthrostylid rhabdomesine cryptostomes (Blake, 1979) with jointed colonies, but these have ball and socket joints at the ends of the branches of which there is no evidence among known material of Pywackia. If the colonies were unjointed, as believed by Landing et al. (2010), the proximal ends of Pywackia rods should contain the first-formed zooids of these small colonies consisting of just one branch. In this case they should preserve a founding zooid (ancestrula) with the bulb-like proximal protoecium that is typical of stenolaemates. Although it is possible to explain the absence of a protoecium in Pywackia by loss through breakage, the elongate proximal modules do not resemble the ancestrula or other astogenetically immature zooids of known bryozoans.

Finally, the existence of zooidal polymorphism in Pywackia can be disputed. No distinct axial zooecia could be identified in any of the samples studied by SEM. The 'small polymorphs' of

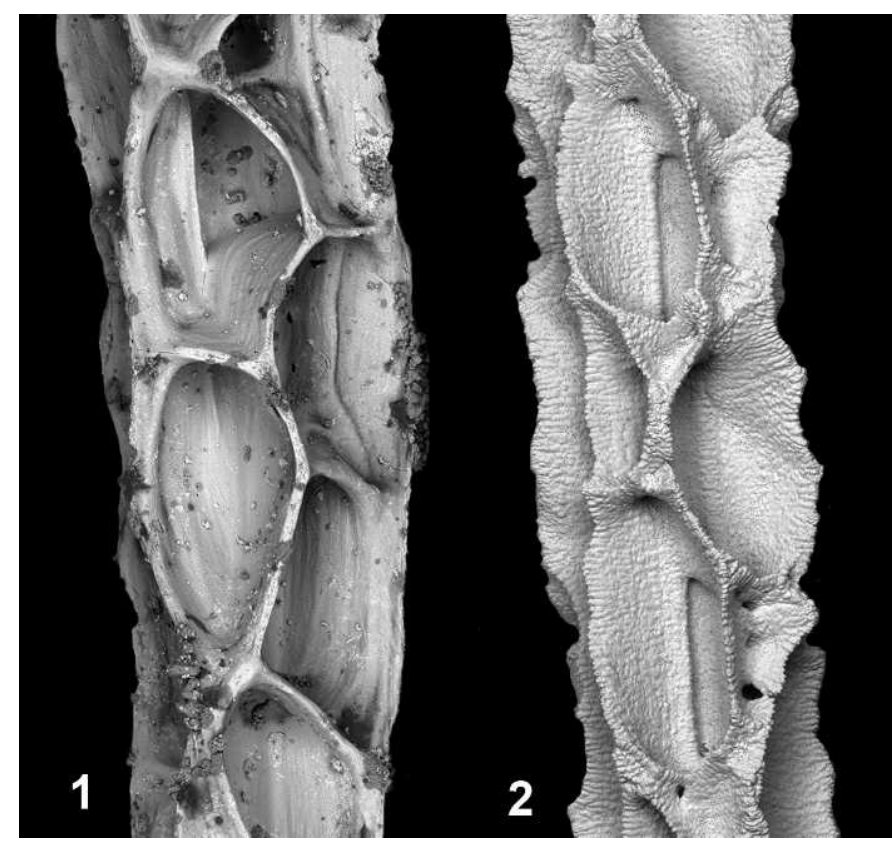

FIGURE 4-Back-scattered scanning electron micrographs illustrating the resemblance between the Cambrian Pywackia baileyi and the axis of the Recent pennatulacean octocoral Lituaria sp. 1, Pywackia baileyi, upper Cambrian, Yudachica Member, Oaxaca State, Mexico, NYSM Tu-2.05, cell $36, \times 78$; 2, Lituaria sp., Recent, sand flat near Changi Ferry Terminal, Singapore, RMS ZRC.CNI.0935, ×13.3.

Landing et al. (2010) seem to represent the smallest modules at the end of a continuous range of size variation - there is no clear evidence of bimodality in size or shape.

Octocoral hypothesis.-The notion that Pywackia is an octocoral cnidarian was raised through the chance discovery by one of us (BB) of a webpage < http://www.wildsingapore.com/ wildfacts/cnidaria/others/pennatulacea/pencil.htm $>$ showing a photograph of the skeleton of a Recent 'sea pencil' from Singapore bearing a striking resemblance to Pywackia. We were able to obtain dried specimens of this animal, collected on our behalf by S.K. Tan (RMS). Gary Williams (California Academy of Sciences), based on images sent to him, was able to identify the Singapore sea pencil as a species of the pennatulacean Lituaria sp. Unlike more familiar pennatulaceans with bilaterally symmetrical, foliose colonies (e.g., Williams, 2011, fig. 7B, C, E, H, I), Lituaria belongs to the family Veretillidae in which colonies are radially symmetrical and cylindrical (Williams, 1995; see Williams, 2011, fig. 7A). The genus is unusual among pennatulaceans in having axes covered by polygonal depressions, each presumably corresponding to the location of a polyp, contrasting with the smooth axes seen in other genera.

The external similarity between Pywackia and Lituaria is clear in Figure 4. Colonies of Lituaria comprise straight axes, lacking bifurcations and tapering at their proximal ends, very like rods of Pywackia. Dimensions, however, are considerably greater than Pywackia: the largest specimen of Lituaria is $250 \mathrm{~mm}$ long with a maximum diameter of $6 \mathrm{~mm}$. The smallest specimen in the collection is about $40 \mathrm{~mm}$ long with a maximum width of 1.82 $\mathrm{mm}$ (Fig. 5.1). Proximal ends of the skeletal axes taper gradually almost to a point (Fig. 5.1), while the distal growing tip has an axial prominence (Fig. 5.2). The comparison with Pywackia is made more compelling by the covering of polygonal modular units very similar to those of the Cambrian fossil: ridge-like longitudinal walls define shallow, cup-like polygonal modules (Fig. 5.1-5.5) over the entire surface of the skeletal axes except 

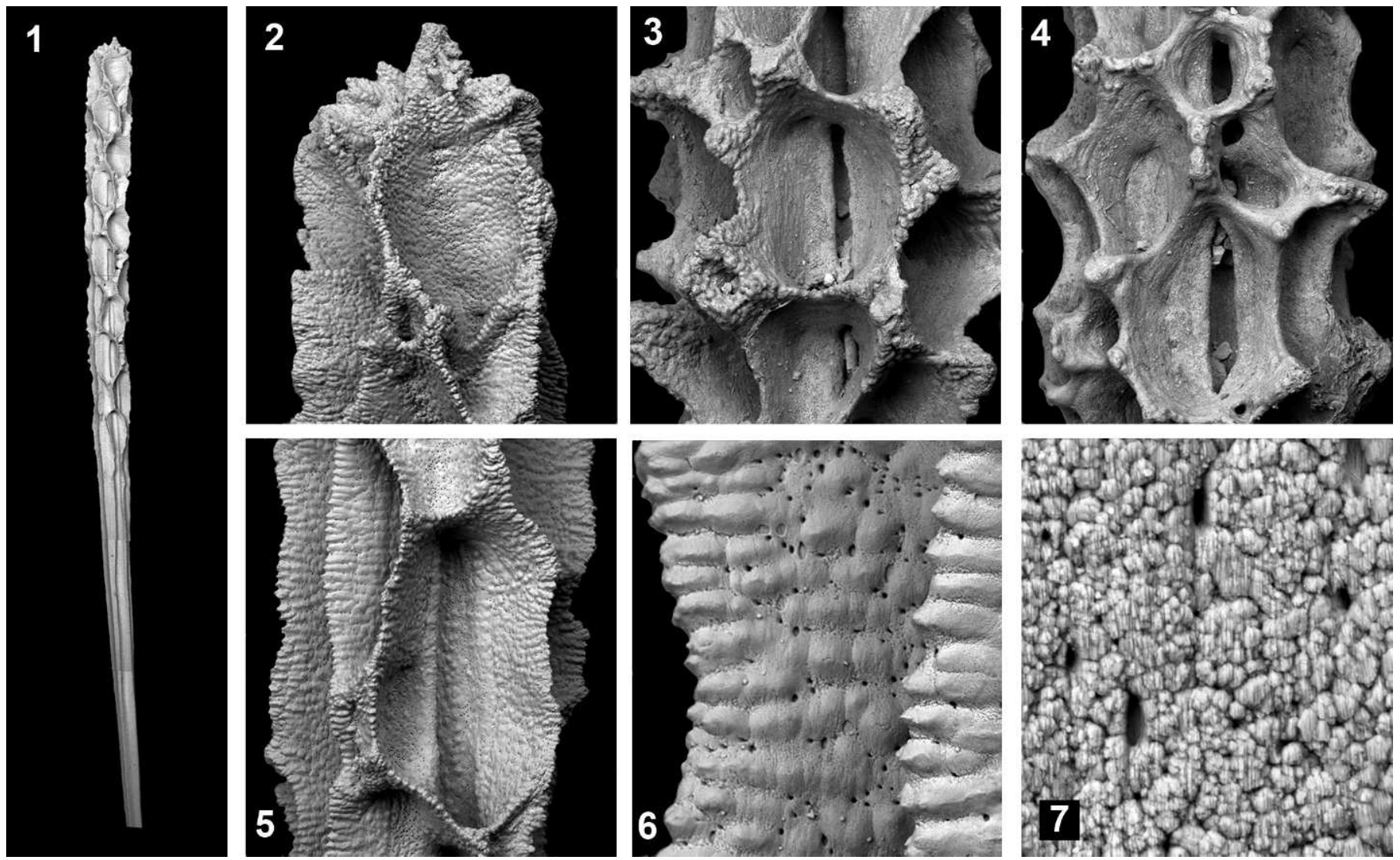

FIGURE 5-Back-scattered scanning electron micrographs of the axis of the pennatulacean octocoral Lituaria sp., Recent, sand flat near Changi Ferry Terminal, Singapore. 1, montage of small, almost complete specimen (proximal apex broken off), RMS ZRC.CNI.0935, ×3.4; 2, distal tip, RMS ZRC.CNI.0935, X17; 3, 4, polygonal modules of variable size and with longitudinal fissures in some of the basal walls, RMS ZRC.CNI.0936 (dried, unbleached), both $\times 28$; 5 , module with a longitudinal keel, RMS ZRC.CNI.0935, $\times 22 ; 6$, profile of the serrated edges of two walls, RMS ZRC.CNI.0935, $\times 110$; 7, microstructure of a skeletal wall surface with granular fabric and occasional pits/pores, RMS ZRC.CNI.0935, ×590.

for the proximal extremities. The modules of Lituaria are elongate and typically measure about $1.3-2.3 \mathrm{~mm}$ long by $0.7-$ $2.0 \mathrm{~mm}$ wide (cf. $0.27-0.59$ by $0.15-0.38 \mathrm{~mm}$ in Pywackia). However, module shape and size shows considerable variation, and some of the modules are as little as $0.2 \mathrm{~mm}$ in diameter (Fig. 5.3). Longitudinal walls of the most proximally situated modules extend as low ridges towards the pointed proximal ends of the axes, very like those of Pywackia (Landing et al., 2010, fig. 2A, B). Elongate gaps can be observed on the basal walls of some zooids (Fig. 5.3, 5.4), recalling some Pywackia specimens, and longitudinal keels may also be present (Fig. 5.5).

Similarities between Lituaria and Pywackia are countered by a few notable differences, in addition to the size contrast between the modules. The walls of the modules are often prolonged at corners into broad, flattened spine-like structures (Fig. 5.4), a feature not seen in Pywackia. In addition, pustules occur over much of the outer parts of wall surfaces (Fig. 5.5). Related to these pustules are serrations developed at the edges of the walls in small specimens (Fig. 5.6). At high magnifications, the ultrastructure of the wall surface is distinctly granular, contrasting with the smooth walls of Pywackia, and small pits are present (Fig. 5.7).

\section{DISCUSSION}

Described as the first Cambrian bryozoan by Landing et al. (2010), Pywackia baileyi is sufficiently different from indisputable bryozoans to question its identification as a bryozoan. Notably, absence of branching and an encrusting base, the non- tubular morphology of the modular units, the irregularity and morphology of partitioning walls within these modules, and the tapered proximal ends of the rods, are largely or totally inconsistent with a bryozoan affinity. The discovery of a modern pennatulacean octocoral showing striking morphological similarities to Pywackia allows an alternative hypothesis to be proposed: that Pywackia represents an octocoral. To evaluate the viability of this hypothesis it is necessary to consider aspects of the phylogeny, fossil record and biomineralization of octocorals.

Octocorallia is a subclass of anthozoan cnidarians that today includes sea pens (Order Pennatulacea), sea whips and fans (Order Gorgonacea), soft corals (Order Alcyonacea), some of which (e.g., Tubipora) have calcareous skeletons, and the biomineralized blue corals (Order Helioporacea). All octocorals are colonial and each polyp has eight tentacles, with a corresponding number of mesenteries. Biomineralization may be lacking or may take the form of calcareous spicules and/or calcified colony axes, depending on the species concerned.

While Octocorallia as a whole is believed to be monophyletic, the inter-relationships between different orders of octocorals have not been satisfactorily resolved, notwithstanding the molecular phylogeny of McFadden et al. (2006). Uncertainties in part reflect the fact that too few taxa of this very diverse and disparate group have been sequenced. With respect to the relationships between octocorals and other major groups of cnidarians, there are two alternative hypotheses: either Octocorallia are the sister-group of Hexacorallia and these two 
subclasses together form the Anthozoa (Collins, 2009), or Octocorallia are the sister-group of Medusozoa (Park et al., 2012). Regardless of their relationships to other groups, octocorals are generally considered to be an ancient group of cnidarians: the calibrated molecular phylogeny of Park et al. (2012) estimated the divergence between octocorals and their sister-group to have occurred in the Neoproterozoic, about 700 Ma.

The fossil record of octocorals is patchy and poorly known, not least because many taxa are unmineralized. An early idea that Charnia and other frond-like fossils (rangeomorphs) are pennatulacean octocorals has lost credibility following detailed morphological comparisons between these Ediacaran fossils and modern pennatulaceans (Williams, 1997; Antcliffe and Brasier, 2007). Convincing octocoral spicules have been described from the Silurian (Bengtson, 1981). Some older fossils have been interpreted as axes of octocorals, notably Echmatocrinus, from the middle Cambrian (Burgess Shale) of British Columbia (Ausich and Babcock, 1998, 2000) and Petilavenula Cope, 2005, from the Lower Ordovician (Arenig) of Wales. Therefore, interpretation of Pywackia as an octocoral is consistent with the known fossil record of octocorals, which extends back with certainty to the Silurian and quite possibly to the Cambrian, as well as molecular estimates of the time of origin of Octocorallia. Moreover, it has been repeatedly suggested that Veretillidae, with their radially symmetrical colonies, are basal pennatulaceans (cf. Williams, 2011, p. 8).

Could Pywackia be a pennatulacean octocoral like its morphological modern analogue Lituaria? Having eliminated rangeomorphs from the fossil record of pennatulaceans, the oldest indisputable pennatulaceans date from the Late Cretaceous. Reich and Kutscher (2011) reviewed the fossil record of pennatulaceans and described some of the oldest known examples: calcitic axes of two species of 'Graphularia' from the Maastrichtian of Germany. The substantial gap (>400 my) in the fossil record from the upper Cambrian Pywackia to the Upper Cretaceous 'Graphularia', seems difficult to explain, let alone the even larger gap ( $\sim 500$ my) from Pywackia to Lituaria. It is unlikely that Pywackia/Lituaria-like fossils would have been completely overlooked, although Lituaria with its peculiar axis is poorly known even in the Recent and it is just possible that fossils have not been identified as such. Alternatively, it is conceivable that a clade bookmarked by these two genera lost biomineralization of the colony axis during its evolution before subsequently regaining it. This idea is hard to test but loss of biomineralization is feasible in view of the occurrence of Recent pennatulaceans without axial biomineralization, such as species of Cavernularia, a veretillid closely related to Lituaria (Williams, 1995).

Even if Pywackia is not a pennatulacean, the similarity between it and Lituaria provides a compelling octocoral alternative to the hypothesized bryozoan affinity of this Cambrian fossil. The straight, proximally tapered and unbranched axes of Lituaria covered by shallow calyx-like modules strongly resemble scaled-up Pywackia rods. At the very least, Lituaria demonstrates the capacity of octocorals to produce colonial skeletons that could easily be mistaken for bryozoans. Although there is a significant contrast in the size of Pywackia and Lituaria, the approximately four-fold module size difference (length $0.3-0.6 \mathrm{~mm}$ in Pywackia vs. $1.3-2.3 \mathrm{~mm}$ in Lituaria) is actually exceeded by the interspecific variation in autozooid diameters of $<1 \mathrm{~mm}$ (in Veretillum tenue) to $7 \mathrm{~mm}$ (in Umbellula durissima) among the modern pennatulacean species described by Hickson (1916). It must be noted, however, that the calyx-like modules of Lituaria need not necessarily correspond exactly to the zooids. Modern pennatulaceans examined by one of us (BB) at the MNHN, showed considerable variability in axis length even within a species.

Many living gorgonian octocorals were shown by Bayer and Macintyre (2001) to contain appreciable amounts of amorphous carbonate hydroxylapatite within their axes. Mcintyre et al. (2000) suggested that this may indicate phosphatic biomineralization early in the evolutionary history of cnidarians. Indeed, the putative Ordovician (Volkhovian) octocoral Nonnegorgonides has a phosphatic axis (Lindström, 1978), while some early Cambrian spicules described by Bengtson (in Bengtson et al., 1990) as Microcoryne that resemble octocoral spicules are preserved in phosphate, although this may represent replacement of an originally calcareous biomineral. Could the skeleton of Pywackia be composed of original rather than diagenetic phosphate? As with some recently described hexacorals from the Lower Ordovician of China which are also preserved as phosphate (Balinski et al., 2012), it is difficult to determine whether the Pywackia skeleton was originally phosphatic. While not conclusive, the non-homogeneous, tripartite structure of Pywackia walls, with dense outer layers sandwiching a central layer containing voids (Fig. 2.10, 2.11), supports the interpretation that the skeleton comprises biogenic phosphate. An originally phosphatic skeleton would be further evidence against the bryozoan affinity of Pywackia, notwithstanding the occurrence of thin phosphatic linings in some Paleozoic bryozoans that may be of bryozoan origin (e.g., Conti and Serpagli, 1988).

In conclusion, Pywackia is here reinterpreted as the biomineralized axis of an octocoral with a very similar organization to that of the modern pennatulacean Lituaria. The living colony of Pywackia is envisaged as a small colonial animal with a mineralized axis covered by polyps, each polyp sitting over one of the polygonal calices. The colony is inferred to have lived with its proximal end buried in sediment, and the distal, polyp-bearing part oriented vertically in the water column, much like comparable modern pennatulaceans (e.g., Imahara and Ogawa, 2006).

Following the elimination of Pywackia from the Bryozoa, the search for unequivocal bryozoans of Cambrian age must continue. Of relevance in this respect are findings from both classical morphological and molecular phylogenetic studies of modern bryozoans suggesting that bryozoans are primitively unmineralized. The most basal clade of bryozoans in most analyses (e.g., Waeschenbach et al., 2012) is the freshwater class Phylactolaemata, which are completely uncalcified, and models of marine bryozoan evolution suggest that the first biomineralized stenolaemates of Ordovician age evolved from uncalcified ctenostome-grade marine ancestors (e.g., see Taylor et al., 2010). Unfortunately, no soft-bodied bryozoans have yet been identified in the classic Cambrian Lagerstätten such as the Burgess Shale or Chengjiang biota. The absence of soft-bodied bryozoans from younger Lagerstätten within the established range of the phylum (e.g., Hunsrück Shale and Solnhofen Limestone) does not provide any grounds for optimism that Cambrian Lagerstätten will furnish soft-bodied bryozoans. Preservation of soft-bodied Cambrian bryozoans by bioimmuration (see Taylor, 1990) is possible but unlikely because of the paucity of skeletonized encrusters capable of producing bioimmurations.

\section{ACKNOWLEDGMENTS}

Above all, we thank E. Landing (New York State Paleontologist) for allowing us to study some of his samples of Pywackia, despite our polarized opinions regarding the affinity of this fossil. We are grateful to R. Tan (Singapore) for creating and 
maintaining the Wild Singapore webpage (www.wildsingapore. com) and photographer Kok Shen (http://www.flickr.com/photos/ koksheng/3841568723/in/photostream). S. K. Tan (Raffles Museum, Singapore) very kindly collected material of recent Lituaria for us, and M. Lowe and C. Sendino (both NHM, London) provided access to collections of modern pennatulaceans and fossil bryozoans, respectively, in their care. Discussions and correspondence about octocorals with G. Williams (California Academy of Sciences), J. Antcliffe (University of Oxford) and M. Reich (University of Göttingen) are gratefully acknowledged. M. Reich and A. Ernst (University of Kiel) kindly read the manuscript, the latter advising about the identities of the bryozoans depicted in Figure 3, and C. Buttler and J. Cope furnished useful reviews. BB acknowledges support from the SYNTHESYS Project (http://www.synthesys.info/), which is financed by European Community Research Infrastructure Action under the FP7 "Capacities" Program, and which allowed study of Recent pennatulaceans at the MNHN (FR-TAF-1902).

\section{REFERENCES}

Antcliffe, J. B. And M. D. Brasier. 2007. Charnia and sea pens are poles apart. Journal of the Geological Society of London 164:49-51.

Ausich, W. I. AND L. E. BABCOCK. 1998. The phylogenetic position of Echmatocrinus brachiatus, a probable octocoral from the Burgess Shale. Palaeontology 41:193-202.

Ausich, W. I. And L. E. BABCOCK. 2000. Echmatocrinus, a Burgess Shale animal reconsidered. Lethaia 33:92-94.

Balinski, A., Y. Sun, AND J. DzIK. 2012. 470-million-year-old black corals from China. Naturwissenschaften, 99:645-653.

Bayer, F. M. AND I. G. Macintyre. 2001. The mineral component of the axis and holdfast of some gorgonacean octocorals (Coelenterata: Anthozoa), with special reference to the family Gorgoniidae. Proceedings of the Biological Society of Washington 114:309-345.

Bengtson, S. 1981. Atractosella, a Silurian octocoral. Journal of Paleontology, 55:281-294.

Bengtson, S., S. Conway Morris, B. J. Cooper, P. A. Jell, and B. N. RunNegar. 1990. Early Cambrian fossils from South Australia. Memoirs of the Australasian Association of Palaeontologists, 9:1-364.

Blake, D. B. 1979. The Arthrostylidae and articulated growth habits in Paleozoic bryozoans, p. 337-344. In G. P. Larwood and M. B. Abbott (eds.), Advances in Bryozoology. Academic Press, London and New York.

BlaKe, D. B. 1983. Introduction to the suborder Rhabdomesina, p. 530-549. In R. A. Robison (ed.), Treatise on Invertebrate Paleontology, Pt. G., Bryozoa, Revised. Volume 1: Introduction, Order Cystoporata, Order Cryptostomata. Geological Society of America and University of Kansas, Boulder and Lawrence.

CobBold, E. S. 1931. Additional fossils from the Cambrian rocks of Comley, Shropshire. Quarterly Journal of the Geological Society of London, 87:459 512.

Cobbold, E. S. and R. W. Pocock. 1934. The Cambrian area of Rushton (Shropshire). Philosophical Transactions of the Royal Society of London, Series B, 223:305-409.

Collins, A. G. 2009. Recent insights into cnidarian phylogeny. Smithsonian Contributions to the Marine Sciences, 38:139-149.

Conti, S. and E. Serpagli. 1988. Bimineralic (calcareous and phosphatic) skeleton in Late Ordovician Bryozoa from Sardinia: geological implications. Bollettino della Societa Paleontologica Italiana, 23:3-20.

Cope, J. C. W. 2005. Octocorallian and hydroid fossils from the Lower Ordovician of Wales. Palaeontology, 48:433-445.
DzIK, J. 1994. Bryozoa of the Mójcza Limestone. Palaeontologia Polonica, 53: 253-282.

Fritz, M. A. 1947. Cambrian Bryozoa. Journal of Paleontology, 21:434 435.

Hickson, S. J. 1916. The Pennatulacea of the Siboga Expedition. SibogaExpeditie, 14:1-265.

Hinds, R.W. 1973, Intrazooecial structures in some tubuliporinid cyclostome Bryozoa, p. 299-306. In G. P. Larwood (ed.), Living and Fossil Bryozoa Academic Press, London.

ImAHARA, Y. AND K. OGawa. 2006. Rediscovery of Virgularia juncea (Octocorallia, Pennatulacea) from a tidal marsh in Okinawa, with a shor note on its peculiar behavior. Proceedings of the 10th International Coral Reef Symposium, p. 9-13.

Kobluk, D. R. 1984. Archaeotrypa Fritz 1947 (Cambrian, Problematica) reinterpreted. Canadian Journal of Earth Science, 21:1343-1348.

Landing, E., A. English, and J. D. Keppie. 2010. Cambrian origin of all skeletalized phyla - discovery of Earth's oldest bryozoans (upper Cambrian, southern Mexico). Geology, 38:547-550.

Landing, E., S. R. Westrop, and J. D. Keppie. 2007. Terminal Cambrian and lowest Ordovician succession of Mexican West Gondwana: biotas and sequence stratigraphy of the Tinu Formation. Geological Magazine, 144: 909-936.

Lindström, M. 1978. An octocoral from the Lower Ordovician of Sweden. Geologica et Palaeontologica, 12:41-52.

Macintyre, I. G., F. M. Bayer, M. A. V. Logan, and H. C. W. Skinner. 2000. Possible vestiges of early phosphatic biomineralization in gorgonian octocorals (Coelenterata). Geology, 28:455-458.

McFadden, C. S., S. C. France, J. A. Sánchez, and P. Alderslade. 2006. A molecular phylogenetic analysis of the Octocorallia (Cnidaria: Anthozoa) based on mitochondrial protein-coding sequences. Molecular Phylogenetics and Evolution, 41:513-527.

Park, E., D.-S. Hwang, J.-S. Lee, J.-I. Song, T.-K. Seo, and Y.-J. Won. 2012. Estimation of divergence times in cnidarian evolution based on mitochondrial protein-coding genes and the fossil record. Molecular Phylogenetics and Evolution, 62:329-345.

Reich, M. and M. Kutscher. 2011. Sea pens (Octocorallia: Pennatulacea) from the Late Cretaceous of northern Germany. Journal of Paleontology, 85:1042-101.

TAYloR, P. D. 1990. Preservation of soft-bodied and other organisms by bioimmuration - a review. Palaeontology, 33:1-17.

TAylor, P. D. And A. ERnst. 2004. Bryozoans, p. 147-156. In B. D. Webby, F Paris, M. L. Droser, and I. G. Percival (eds.), The Great Ordovician Biodiversification Event. Columbia University Press, New York.

TAYlor, P. D., O. VInN, AND M. A. Wilson. 2010. Evolution of biomineralisation in 'lophophorates'. Special Papers in Palaeontology, 84: 317-333

Waeschenbach, A., P. D. Taylor, and D. T. Littlewood. 2012. A molecular phylogeny of bryozoans. Molecular Phylogenetics and Evolution, 62:718735.

WiLliams, G. C. 1995. Living genera of sea pens (Coelenterata: Octocorallia: Pennatulacea): illustrated key and synopses. Zoological Journal of the Linnean Society, 113:93-140.

Williams, G. C. 1997. Preliminary assessment of the phylogeny of Pennatulacea (Anthozoa: Octocorallia), with a reevaluation of Ediacaran frond-like fossils, and a synopsis of the history of evolutionary thought regarding the sea pens. Proceedings of the 6th International Conference on Coelenterate Biology, 1995, p. 497-509.

Williams, G. C. 2011. The global diversity of sea pens (Cnidaria: Octocorallia: Pennatulacea). PLoS ONE, 6, e22747.

Wyse Jackson, P. N. And A. J. Bancroft. 1995. Generic revision of the cryptostome bryozoan Rhabdomeson Young and Young, 1874, with descriptions of two species from the Carboniferous of the British Isles. Journal of Paleontology, 69:28-45.

ACCEPTED 7 March 2013 